\title{
FRUGIVORY AND DISPERSAL OF Faramea cyanea (RUBIACEAE) IN CERRADO WOODY PLANT FORMATIONS
}

\author{
MELO, C., ${ }^{1}$ BENTO, E. C. ${ }^{2}$ and OLIVEIRA, P. E. ${ }^{2}$ \\ ${ }^{1}$ Pós-graduação em Ecologia, Departamento de Ecologia, Instituto de Biologia, Universidade de Brasília, \\ CEP 70910-900, Brasília, DF, Brazil \\ ${ }^{2}$ Instituto de Biologia, Universidade Federal de Uberlândia, CEP 38400-750, Uberlândia, MG, Brazil \\ Correspondence to: Celine Melo, Rua Feliciano de Morais, 2743, Bairro Custódio Pereira, CEP 38405-188, \\ Uberlândia, MG, Brazil, e-mail: celinemelo@aol.com \\ Received October 23, 2001 - Accepted April 9, 2002 - Distributed February 28, 2003
}

(With 3 figures)

\begin{abstract}
The objective of this study was to observe and compare the community of birds that utilize the tree species Faramea cyanea, in contiguous areas of cerradão and gallery forest, and also to characterize the behavioral patterns of the birds. The study was carried out in the Panga Ecological Station (Uberlândia, Minas Gerais State), in April and May 2001. Nine individuals of $F$. cyanea were observed in periods between 06:45-11:30 h for a total of 44.5 hours. There were 204 visits by 13 bird species. Tyrannidae was the most represented family (five species) and Turdidae, the most frequent ( $72.1 \%$ of visits). The number of consumed fruits was correlated with the permanence time on the plant. There was no significant difference between the two forests habitats, in terms of foraging tactics or fruit consumption strategies. In spite of the predominance of omnivorous birds (89.5\%) in both habitats, the swallower strategy $(84.2 \%)$ indicates high seed dispersal potential. Antilophia galeata, a frugivorous bird, presented the greatest rate of consumed fruits per minute in both gallery forest (2.15) and cerradão (1.06).
\end{abstract}

Key words: birds, fruit dispersal, gallery forest, cerradão, frugivory.

\section{RESUMO}

\section{Frugivoria e dispersão de Faramea cyanea (Rubiaceae) em formações florestais no Cerrado}

O objetivo deste estudo foi observar e comparar a comunidade de aves que utiliza Faramea cyanea, em áreas contíguas de cerradão e mata de galeria, e caracterizar o padrão comportamental das aves. O estudo foi conduzido na Estação Ecológica do Panga (Uberlândia, MG), em abril e maio de 2001. Nove indivíduos de F. cyanea foram observados entre $6 \mathrm{~h} 45$ e $11 \mathrm{~h} 30$, totalizando 44,5 horas de observação. Houve 204 visitas por 13 espécies de aves. Tyrannidae foi a família mais representativa (cinco espécies) e Turdidae, a mais freqüente ( $72,1 \%$ das visitas). O número de frutos consumidos foi correlacionado ao tempo de permanência na planta. Não houve diferença significativa entre os ambientes, em termos de táticas de forrageamento ou estratégias de consumo de frutos. Apesar da predominância de aves onívoras $(89,5 \%)$ em ambos os ambientes, a estratégia engolidor $(84,2 \%)$ indica maior potencial para dispersão de sementes. Antilophia galeata, que é frugívora, apresentou a maior taxa de consumo de frutos por minuto na Mata de Galeria $(2,15)$ e no Cerradão $(1,06)$.

Palavras-chave: aves, dispersão de frutos, Mata de Galeria, Cerradão, frugivoria. 


\section{INTRODUCTION}

Zoocory, specially ornithocory, are common dispersal syndromes in the Cerrado biome (Mantovani \& Martins, 1988; Miranda, 1995; Pinheiro, 1999), particularly in gallery forests (Pinheiro, 1999). However, anthropogenic disturbance in the Cerrado has resulted in a reduced diversity of pollinators and dispersers, both agents of considerable importance in the maintenance of the vegetation (Oliveira, 1994). Information about dispersal relationships is important to define management strategies and environmental conservation.

In the Cerrado of Central Brazil, some zoochorous species offer fruits out of the peak fruiting time, which occurs in the wet season, between October and January (Oliveira, 1998; Pinheiro, 1999). Such fruiting displacement may be a strategy to use the presence of temporary migratory dispersers (Pinheiro, 1999) or avoid competition with the local fauna. In this way, species that offer mature fruits during the dry season may attract and benefit the dispersers, since they represent an important resource in a time of scarcity.

Faramea cyanea is a tree species of the Rubiaceae common in forest areas in Central Brazil, with minimum high about $3 \mathrm{~m}$ and maximum $6 \mathrm{~m}$. Flowering occurs in October, and the fruiting period is from January to August (C. E. Tomé, 2001, personal communication), but the peak offering of mature fruits occurs in April and May (C. Melo, personal observation). Dispersal occurs at the beginning of the dry season, when, in general, there is a smaller quantity of fruits available in the Cerrado biome (Oliveira, 1994).

The objective of this study was to observe the community of frugivorous birds associated with $F$. cyanea and to compare their occurrence in contiguous gallery forest and cerradão habitats, and also to characterize frugivorous bird behavior, foraging tactics and fruit consumption strategies.

\section{MATERIAL AND METHODS}

\section{Study area}

Panga Ecological Station $\left(19^{\circ} 09^{\prime}-19^{\circ} 11^{\prime} \mathrm{S}\right.$ e $48^{\circ} 23^{\prime}-48^{\circ} 24^{\prime} \mathrm{W} ; 800 \mathrm{~m}$ ) is located near Uberlândia, Minas Gerais State, Brazil. It has an area of approximately $409.5 \mathrm{ha}$. The climate is Aw, according to Köppen classification, tropical seasonal with well-defined dry and wet seasons
(Rosa et al., 1991). The vegetation is Cerrado sensu lato with savanna and forest plant formations (Schiavini \& Araújo, 1989). This study was carried out in two contiguous areas: a cerradão, dense woodland and a gallery forest, a seasonally flooded along the Panga stream.

\section{Behavioral observations}

The observations were carried out in April and May, 2001. Four trees of Faramea cyanea in gallery forest and five in cerradão were monitored in the mornings, between $06: 45 \mathrm{~h}$ and 11:30 h, for a total of 44.5 hours. In the morning at every 15 minutes an interval was repeated five times in the cerradão. In the gallery forest, observations from $06: 45 \mathrm{~h}$ to $07: 15 \mathrm{~h}$ and from $11: 00 \mathrm{~h}$ to $11: 30 \mathrm{~h}$, were repeated, respectively, three and two times. Thus, in gallery forest, the observations totaled 21 hours and $15 \mathrm{~min}$., whereas in cerradão they were 23 hours and $45 \mathrm{~min}$. Observations were made using $7 \times 25$ and $10 \times 25$ binoculars.

The following was recorded for each bird visit: (a) the bird species (Frisch, 1981), (b) time of arrival and departure on the plant, (c) number of consumed fruits, (d) foraging tactic and (e) consumption strategy. The predominant diet for each bird species was obtained from literature sources (Antas \& Cavalcanti, 1988; Sick, 1988; Dubs, 1992; Andrade, 1997).

Foraging tactics were classified as either perching or flying. Perching was considered when the bird remained on the plant while taking and eating fruits. In the flying foraging tactic, the bird arrived at the plant, took a fruit and ate it in another place.

The birds were classified according to their consumption strategies following Schupp (1993): swallowers, consume the whole fruit with the seeds; mashers, handle the fruits with the bill and only the pulp and juice are swallowed, and biters, remove portions of the pulp, drilling or pecking the fixed fruit on the plant.

The Jaccard Similarity Index (Greig-Smith, 1983) was used to compare the bird visitors between the two habitats. The Chi-square test was used to compare the gallery forest and cerradão in terms of frequency of foraging tactics, consumption strategies and standard diet of the visitants. Spearman correlation was used to check if the permanence time on the plants was proportional to the number of fruits consumed. 


\section{RESULTS}

The fruits of Faramea cyanea are fleshy drupes one-seed (fresh one-seed drupes?). Ripe fruits are dark purple. A hundred fruits and seeds were measured and weighed. The fruits are $7.9 \mathrm{~mm} \pm$ 0.86 long and $8.9 \mathrm{~mm} \pm 0.81$ of wide. The moist fruit biomass is about $0.48 \mathrm{~g} \pm 0.10$. Seeds are 4.42 $\mathrm{mm} \pm 0.44$ long, $6.9 \mathrm{~mm} \pm 0.6$ of wide. The seed biomass is about $0.15 \mathrm{~g} \pm 0.04$.

A total of 204 visits were recorded, 142 of these in the gallery forest and 62 in the cerradão. Thirteen species visited $F$. cyanea, ten in the gallery forest and seven in the cerradão, a similarity index between habitats was 0.59 . Tyrannidae was the most represented family (five species) and Turdidae the most frequent $(72.1 \% ; 147$ visits $)$. The main species were Turdus leucomelas (40.2\%; 82 visits) and Turdus amaurochalinus (21.1\%; 43 visits) (Table 1).

The peak visiting time in the cerradão area was between 09:15 h and 09:30 h. In the gallery forest there were three concentrated peaks from 09:45 h to 11:00 h (Fig. 1).

Considering the two habitats simultaneously, in terms of number of visits, there was a predominance of omnivorous birds $(89.5 \% ; 180$ visits), followed by frugivorous $(8.5 \% ; 17$ visits) and insectivorous $(2.0 \%, 4$ visits) (Table 1). There was significant difference in the standard diet of visitors between cerradão and gallery forest $\left(\chi^{2}=\right.$ $6.45 ; \mathrm{df}=2 ; \mathrm{p}=0.05)$.

The average time of visits in each plant varied from $0.93 \pm 0.62 \mathrm{~min}$. (Antilophia galeata) to $7.54 \pm$ 3.51 min. (Elaenia sp.) (Table 2). The number of consumed fruits was positively correlated to time of visit $\left(\mathrm{r}_{\mathrm{s}}=0,3411 ; \mathrm{df}=1 ; \mathrm{p}<0.001\right)$. During the visits, the consumption of one or two fruits was more common (64.4\%; in gallery forest and 58.8\%; in cerradão) (Fig. 2).

Antilophia galeata, a highly frugivorous bird (Marini, 1992), presented the best dispersal potential, due to its highest number of fruits consumed by minute in gallery forest $(2.15)$ and in cerradão (1.06). The omnivorous species $T$. leucomelas (0.94 and 0.85, gallery forest and cerradão, respectively) and $T$. amaurochalinus (0.80 and 0.64, gallery forest and cerradão, respectively) were also important (Table 2). The number of consumed fruits by time of permanence on the plant was ignored in the general analysis when birds recorded only once or twice.

The perching foraging tactic was more common (82.3\%; 130 visits) than flying, with no significant difference between the habitats $\left(\chi^{2}=\right.$ $0.19 ; \mathrm{df}=1 ; \mathrm{p}=0.05)$. The swallower strategy $(84.2 \% ; 139$ visits) was the most used in both habitats (Fig. 3). Gallery forest and cerradão were similar in fruit consumption strategy $\left(\chi^{2}=2.24\right.$; df $=2 ; \mathrm{p}=0.05)$. Regurgitated seeds were observed in a few cases. T. amaurochalinus regurgitated one seed after 4 min. perching, and T. rufiventris, two seeds after perching for $3 \mathrm{~min}$.

\section{DISCUSSION}

The presence of open habitat birds inside the forest (e.g., Tyrannidae species) has been considered a strategy to obtain resources during the dry season in the Cerrado biome (Cavalcanti, 1992). As these birds have large home-range areas, it can be advantageous for plants like $F$. cyanea to offer fruits to these potential dispersers. These birds are important in the recovery of degraded areas, because they consume fruits in forest habitats and carry seeds of pioneer species to open disturbed areas, thus accelerating succession (Guedes et al., 1997).

According to Motta-Júnior (1990), there is a predominance of omnivorous birds, in disturbed environments, with the opposite occurring for frugivorous ones. It is possible that the studied area or at least its surroundings present a disturbance level that has affected the frugivorous bird community, leading to omnivorous bird domination (e.g., Turdidae family) in association with $F$. cyanea. This disturbance, may be isolation of the reserve by farmlands, seems to have affected the general bird fauna of the local forest habitats, which is also dominated by omnivorous and insectivorous species (C. Melo, personal observation).

The birds that swallow $F$. cyanea fruits, in general, made brief visits to the plants. This is a behavior that characterizes them as good dispersers, because it reduces the number of seeds regurgitated near the mother-plant (Motta-Júnior \& Lombardi, 1990). Bird mobility is an adaptation for foraging (Gill, 1990), which allows to use larger areas, including distinct habitats, like cerrado and forest edges (Cavalcanti, 1992). 
TABLE 1

Temporal distribution of bird species on Faramea cyanea plants. Diet: $I=$ insects; $F=$ fruits; $I n=$ invertebrates; $V=$ vertebrates. Habitat: $\mathrm{Fo}=$ forest; $\mathrm{Cw}=$ cerrado woodland; $\mathrm{Sf}=$ swamp forest; $\mathrm{Ca}=$ cultivated areas; $\mathrm{Op}=$ open areas; $\mathbf{O r}=$ orchards; $\mathbf{G r}=$ groves.

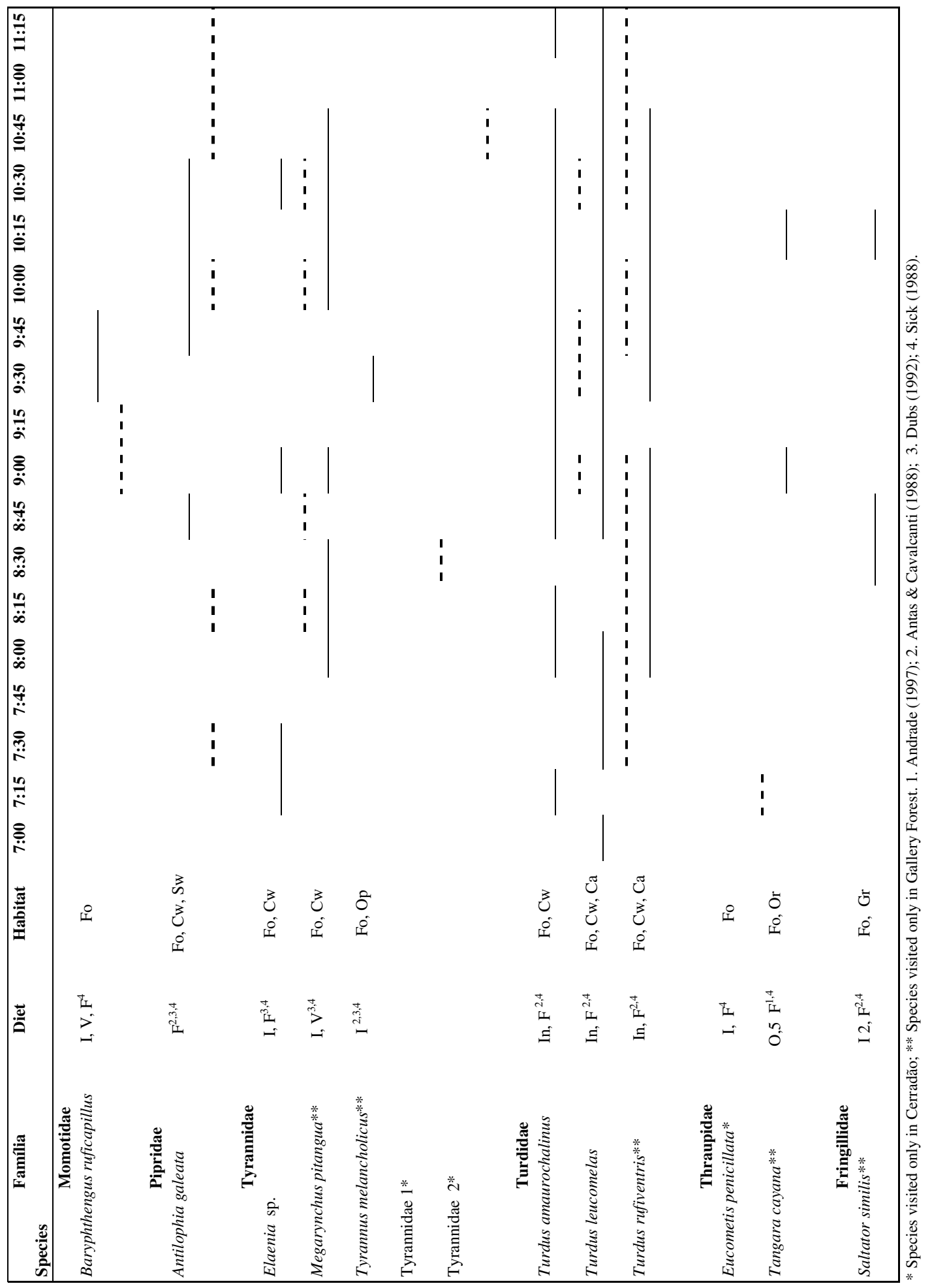

Braz. J. Biol., 63(1): 75-82, 2003 
TABLE 2

Visiting time and fruit consumption in $F$. cyanea. Mean \pm standard deviation (n). $\mathrm{S}=\mathrm{swallower}$; $\mathbf{M}=$ masher and $\mathbf{B}=$ biter.

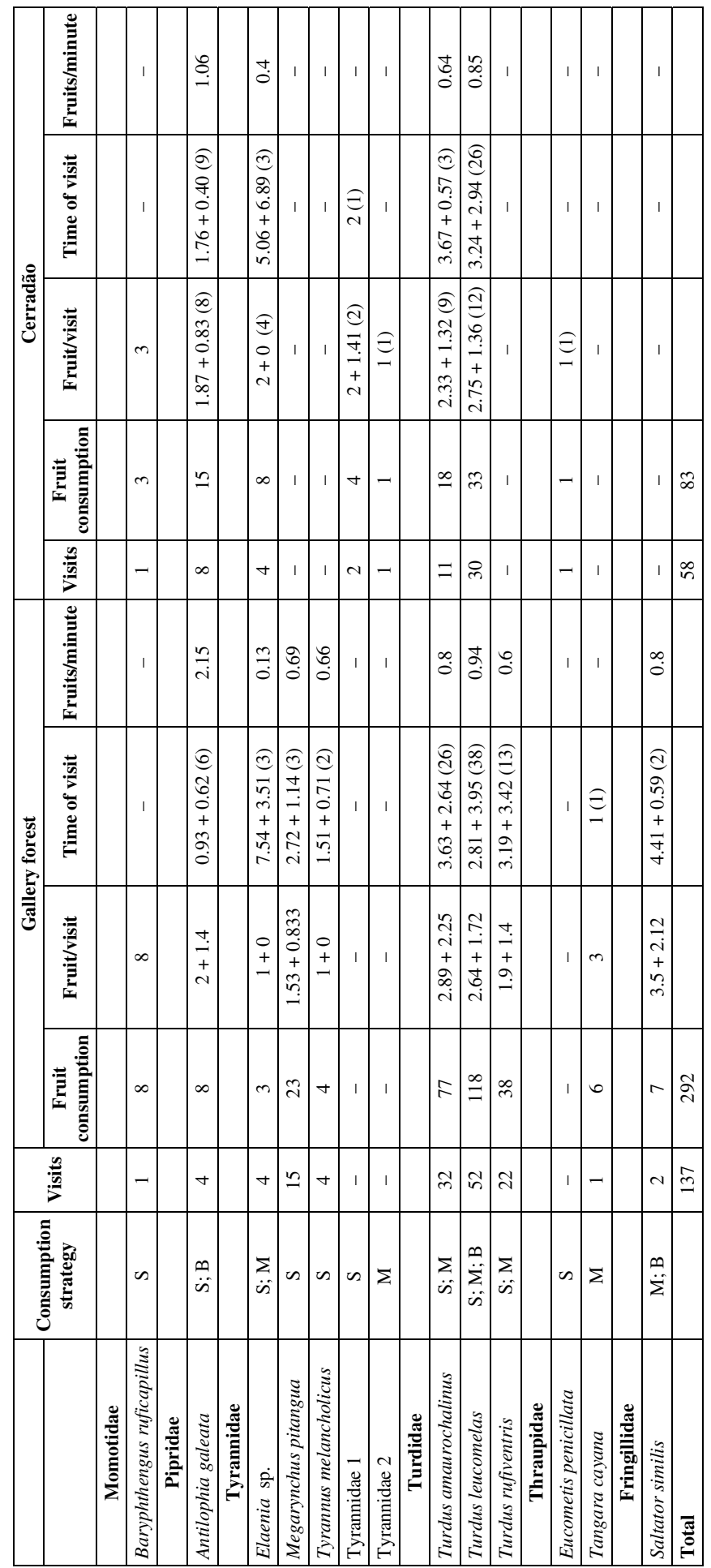




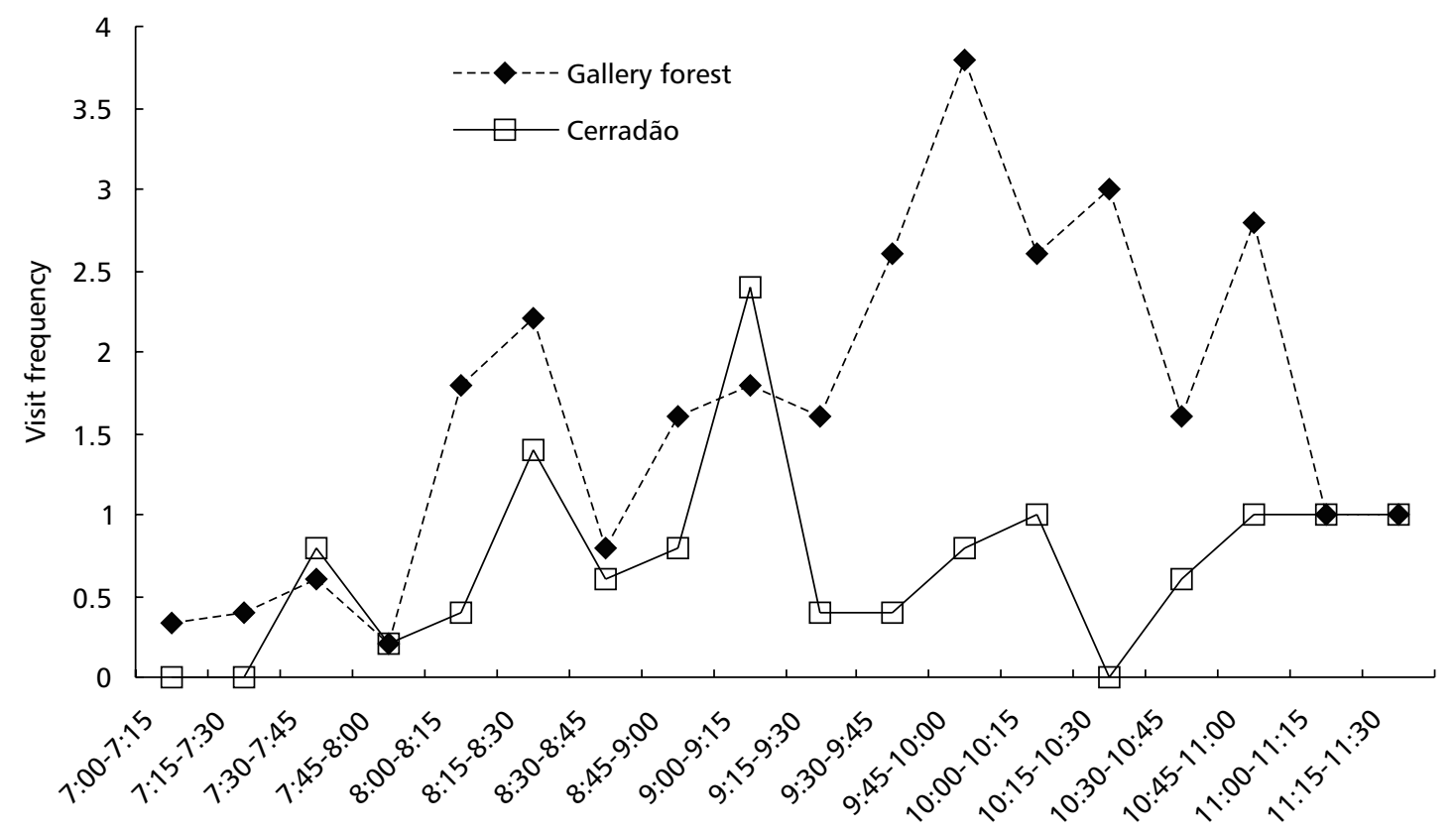

Fig. 1 - Visit frequency (mean number of visits by each interval of $15 \mathrm{~min}$.) to $F$. cyanea plants in gallery forest $(\mathrm{N}=142)$ and cerradão $(\mathrm{N}=62)$ habitats.

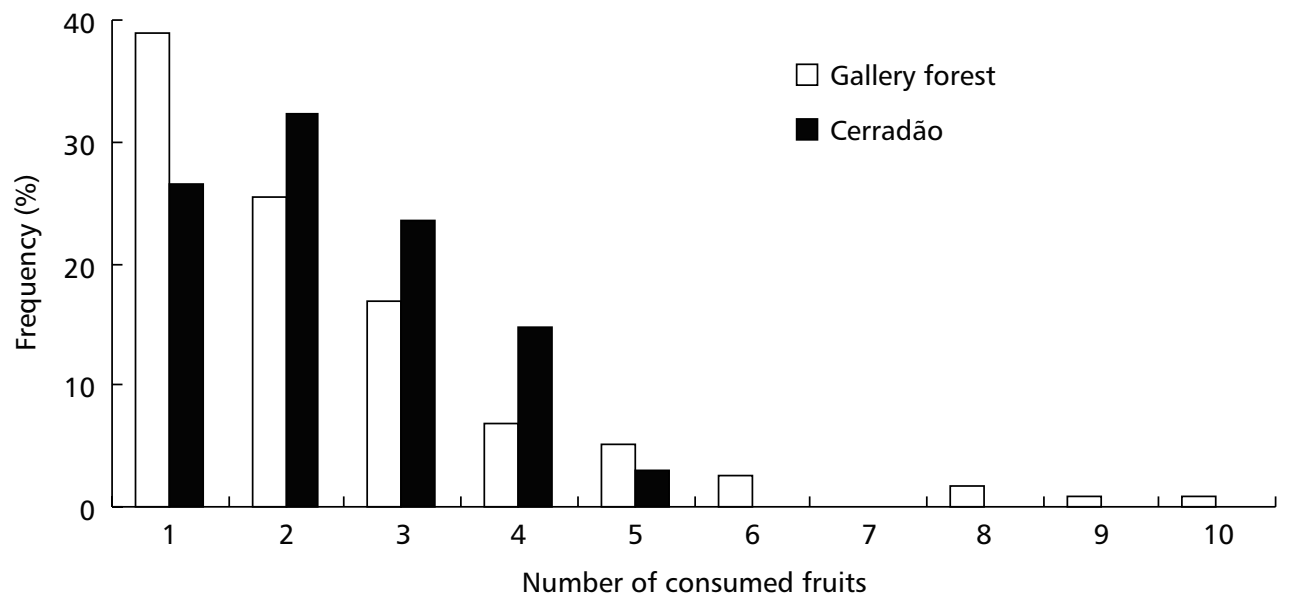

Fig. 2 - Frequency rate of consumed fruits by birds in each visit to $F$. cyanea in cerradão $(\mathrm{N}=34)$ and gallery forest $(\mathrm{N}=$ 118). 


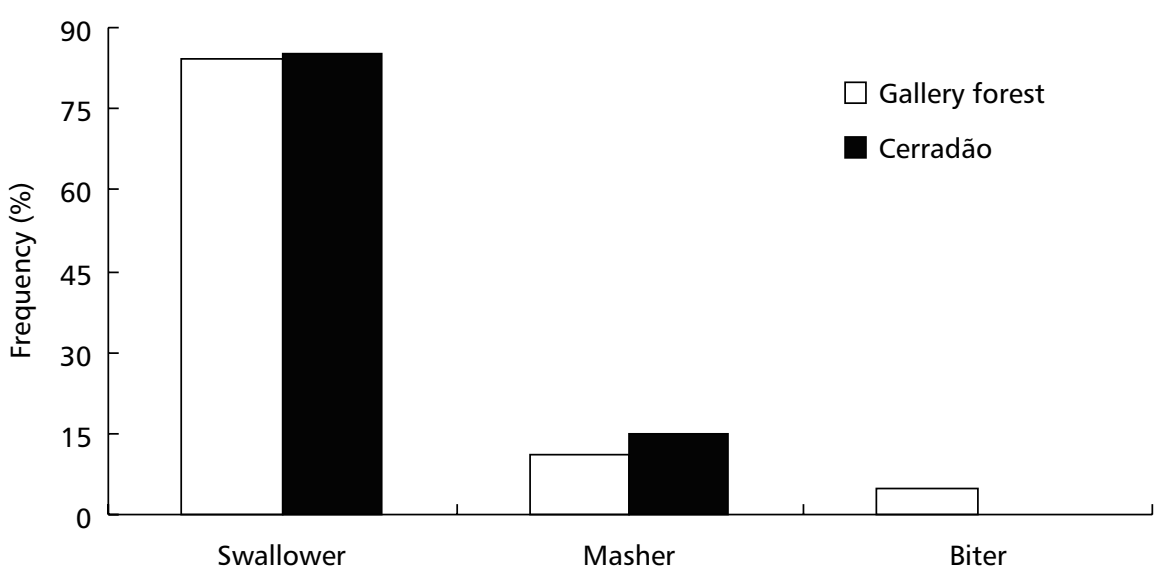

Fig. 3 - Frequency of fruit consumption strategies used in gallery forest $(\mathrm{N}=125)$ and cerradão $(\mathrm{N}=40)$.

In spite of the high frequency of visits by omnivorous birds, highly frugivorous ones such as Antilophia galeata presented the best conditions for dispersal: greater quantity of consumed fruits in less time. However, dispersal potential involves more than high rates of ingestion. Good dispersal ability also includes the choice of mature fruits, seed removal away from vicinity of the motherplant and deposition of uninjured seeds (Murali, 1997).

The use of the perching foraging tactic is apparently more advantageous because it allows the bird to choose the fruit for consumption, to increase the number of fruits consumed in less time, and to reduce the energy loss in order to obtain the fruit resource. In the flying tactic, the bird can take away only one or a few fruits, into limited opportunity to choose the collected ones.

According to Schupp (1993), the use of the swallowers strategy implies higher probability for seed dispersal, and this strategy was used even by omnivorous birds. Since they consume fruits whole and are predominant in both habitats, and even capable of moving between them, omnivorous birds are important in F. cyanea dispersion. Turdus leucomelas and $T$. amaurochalinus can be considered as important as strictly frugivorous species for seed dispersal of $F$. cyanea.

Seed viability after dispersal was not tested to confirm the relative importance of each disperser bird. However, theoretically, at least, fruit maturation during the dry season allows $F$. cyanea to attract an array of potential dispersors. These birds present behavioral foraging strategies suggesting that whether strictly frugivorous or not, all visiting birds may act as good seed dispersers.

Acknowledgments - This study is part of the doctoral thesis of C. Melo (CNPq doctoral grant process 140840/99-0). E. $\mathrm{C}$. Bento has an undergraduate research initiation grant $(\mathrm{CNPq}$ 101103/00-0). C. E. Tomé and Adriana Arantes collaborated with information about the plant. We're grateful to Regina H. F. Macedo (UnB), John D. V. Hay (UnB) and Peter E. Gibbs (University of St. Andrews/CNPq) for their help with the English translation.

\section{REFERENCES}

ANDRADE, M. A., 1997. Aves silvestres: Minas Gerais. Líttera Maciel Ltda., Belo Horizonte, 175p.

ANTAS, P. T. \& CAVALCANTI, R. B., 1988, Aves comuns do Planalto Central. Universidade de Brasília, Brasília, 238p.

CAVALCANTI, R. B., 1992, The importance of forest edges in the ecology of open country cerrado birds, pp. 513518. In: P. A. Furley, J. Proctor \& J. A. Ratter (ed.), Nature and dynamics of forest-savanna boundaries. Chapman and Hall, Londres, 616p.

DUBS, B., 1992, Birds of southwestern Brazil. BetronaVerlag, Küsnacht, 164p.

FRISCH, J. D., 1981, Aves brasileiras. Dalgas-Ecoltec Ecologia Técnica e Comércio Ltda., São Paulo, 353p.

GILL, F. B., 1990, Ornithology. W. H. Freeman and Company, New York, 660p. 
GREIG-SMITH, P., 1983. Quantitative Plant Ecology. Blackwell Scientific Publications, Oxford, $9^{\text {th }}$ vol., $3^{\text {rd }}$ ed., $359 \mathrm{p}$.

GUEDES, M. C., MELO, V. A. \& GRIFFITH, J. J., 1997, Uso de poleiros artificiais e ilhas de vegetação por aves dispersoras de sementes. Ararajuba, 5(2): 229-232.

MANTOVANI, W. \& MARTINS, F. R., 1988, Variações fenológicas das espécies do cerrado da Reserva Biológica de Moji-Guaçu, Estado de São Paulo. Rev. Brasil. Bot., 11: 101-112.

MARINI, M. Â., 1992, Foraging behavior and diet of Helmeted Manakin. The Condor, 94: 151-158.

MIRANDA, I. S., 1995, Fenologia do estrato arbóreo de uma comunidade de cerrado em Alter-do-Chão, PA. Rev. Brasil. Bot., 18(2): 235-240.

MOTTA-JÚNIOR, J. C., 1990, Estrutura trófica e composição das avifaunas de três habitats na região central de São Paulo. Ararajuba, 1: 65-71.

MOTTA-JÚNIOR, J. C. \& LOMBARDI, J. A., 1990, Aves como agentes dispersores da copaíba (Copaifera langsdorfii, Caesalpinaceae) em São Carlos, Estado de São Paulo. Ararajuba, 1: 105-106.

MURALI, K. S., 1997, Patterns of seed size, germination and seed viability of tropical tree species in Southern India. Biotropica, 29(3): 271-279.
OLIVEIRA, P. E., 1994, Aspectos da reprodução de plantas do cerrado e conservação. Bol. Herb. Ezechias Paulo Heringer., 1: 34-45.

OLIVEIRA, P. E., 1998, Fenologia e biologia reprodutiva das espécies de cerrado, pp. 167-192. In: S. M. Sano \& S. P. Almeida (eds.), Cerrado: ambiente e flora. EMBRAPA-CPAC, Planaltina, 556p.

PINHEIRO, F., 1999, Sindromes de dispersão de sementes de matas de galeria do Distrito Federal. Tese de Mestrado, Universidade de Brasília.

ROSA, R., LIMA, S. C. \& ASSUNÇÃO, W. L., 1991, Abordagem preliminar das condições climáticas de Uberlândia (MG). Sociedade \& Natureza, 3(5-6): 91-108.

SCHIAVINI, I. \& ARAÚJO, G. M., 1989, Considerações sobre a vegetação da Reserva Ecológica do Panga (Uberlândia). Sociedade \& Natureza, 1(1): 61-66.

SCHUPP, E. W., 1993, Quantity, quality and the effectiveness of seed dispersal by animals. Vegetatio, 107-108: 15-29.

SICK, H., 1988, Ornitologia brasileira: uma introdução. Universidade de Brasília, Brasília, $1^{\text {st }}$ and $2^{\text {nd }}$ vol., $3^{\text {rd }}$ ed., 827p. 